Groundwater and Streamflow Information Program

\title{
Water-Level and Recoverable Water in Storage Changes, High Plains Aquifer, Predevelopment to 2015 and 2013-15
}

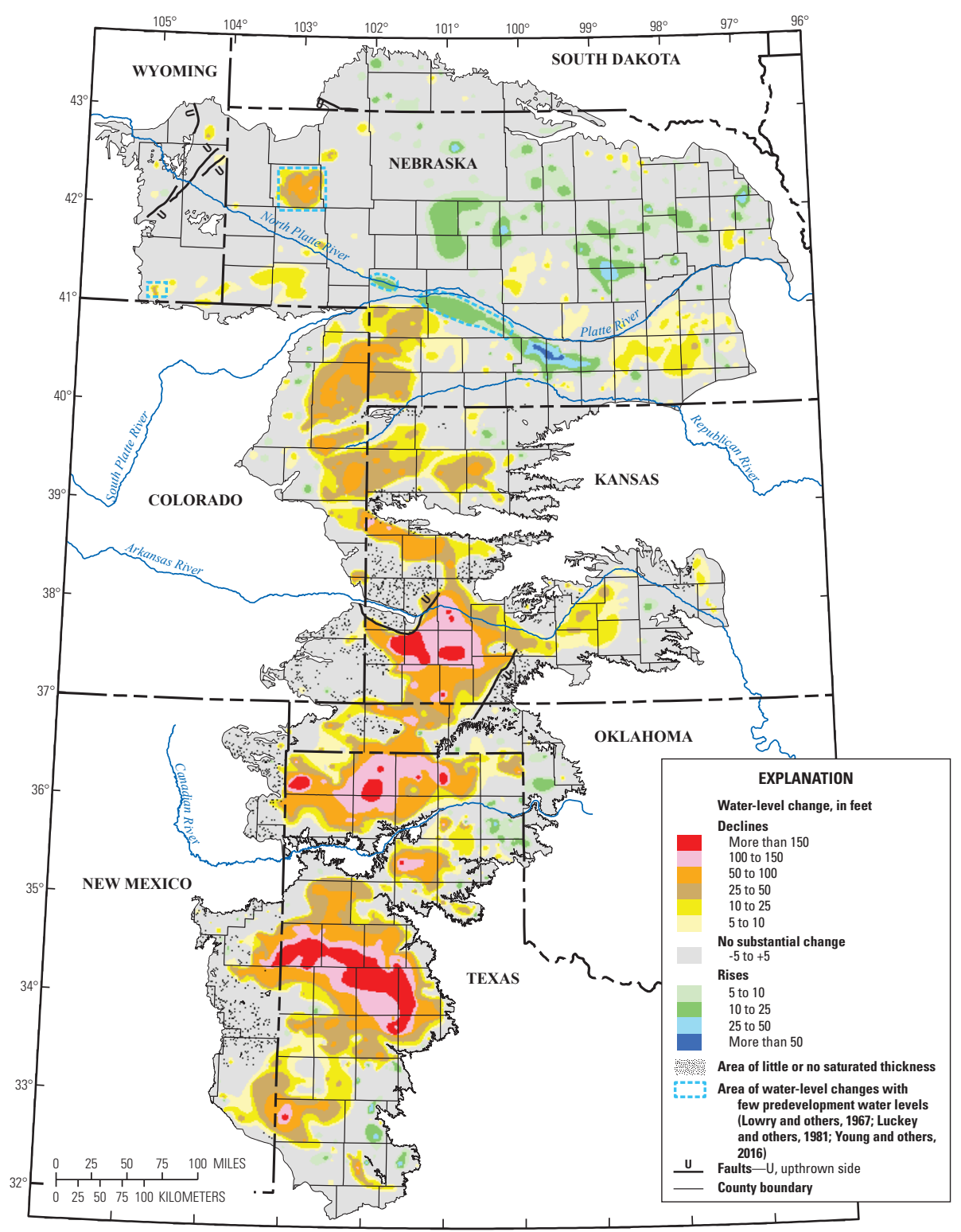

Scientific Investigations Report 2017-5040 
Cover. Figure 1 from this report. 


\section{Water-Level and Recoverable Water in Storage Changes, High Plains Aquifer, Predevelopment to 2015 and 2013-15}

By Virginia L. McGuire

Groundwater and Streamflow Information Program

Scientific Investigations Report 2017-5040 


\title{
U.S. Department of the Interior \\ RYAN K. ZINKE, Secretary
}

\section{U.S. Geological Survey William H. Werkheiser, Acting Director}

\author{
U.S. Geological Survey, Reston, Virginia: 2017
}

For more information on the USGS - the Federal source for science about the Earth, its natural and living resources, natural hazards, and the environment—visit http://www.usgs.gov or call 1-888-ASK-USGS.

For an overview of USGS information products, including maps, imagery, and publications, visit https://store.usgs.gov.

Any use of trade, firm, or product names is for descriptive purposes only and does not imply endorsement by the U.S. Government.

Although this information product, for the most part, is in the public domain, it also may contain copyrighted materials as noted in the text. Permission to reproduce copyrighted items must be secured from the copyright owner.

Suggested citation:

McGuire, V.L., 2017, Water-level and recoverable water in storage changes, High Plains aquifer, predevelopment to 2015 and 2013-15: U.S. Geological Survey Scientific Investigations Report 2017-5040, 14 p., https://doi.org/10.3133/ sir20175040.

ISSN 2328-0328 (online) 


\section{Acknowledgments}

Most of the water-level data used in this report were provided to the U.S. Geological Survey by the following State, local, and Federal entities: Colorado-Division of Water Resources (also known as the Office of the State Engineer); Kansas-Department of Agriculture, Division of Water Resources and the Kansas Geological Survey; Nebraska-Central Nebraska Public Power and Irrigation District, Natural Resources Districts, and University of Nebraska-Lincoln, Conservation and Survey Division; New Mexico-Office of the State Engineer; Oklahoma-Water Resources Board; South Dakota—Department of Environment and Natural Resources; TexasGroundwater Conservation Districts and the Water Development Board; Wyoming — State Engineer's Office; and Federal—Bureau of Reclamation and U.S. Fish and Wildlife Service. The author thanks the above entities for providing the water-level data and for their responsiveness regarding questions about the data. 



\section{Contents}

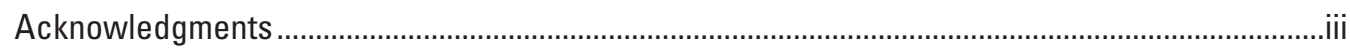

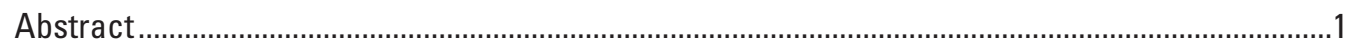

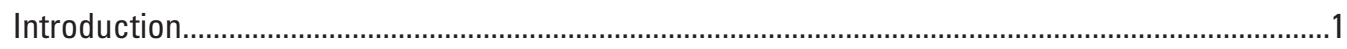

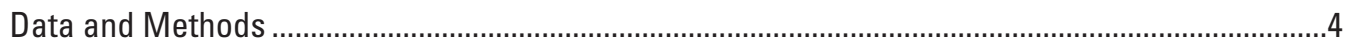

Characteristics of Raster Datasets ..........................................................................................

Characteristics of Water-Level Data .......................................................................................

Characterizing Water-Level Changes, Predevelopment to 2015 ...........................................5

Characterizing Water-Level Changes, 2013-15 ...............................................................6

Characterizing Specific Yield ..........................................................................................

Calculation of Area-Weighted, Average Water-Level Changes, Predevelopment to 2015

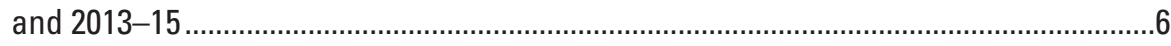

Calculation of Total Recoverable Water in Storage and Change in Recoverable Water in

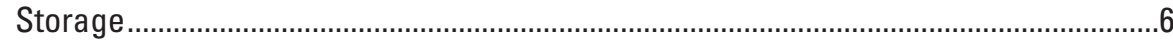

Characterizing Percentage Change in Saturated Thickness, Predevelopment to 2015 ..........6

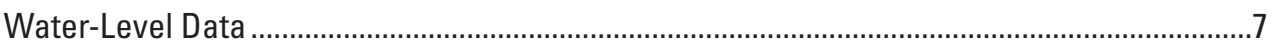

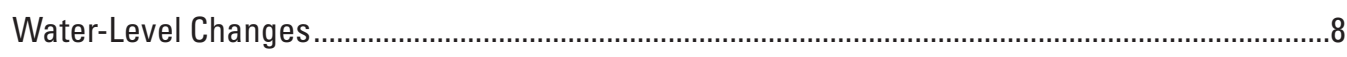

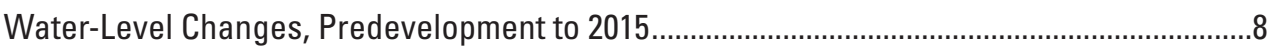

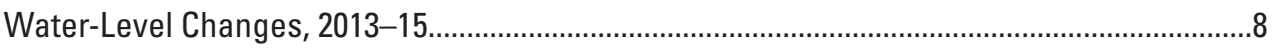

Percentage Change in Saturated Thickness, Predevelopment to 2015 ..................................10

Change in Recoverable Water in Storage, Predevelopment to 2015 and 2013-15 .........................10

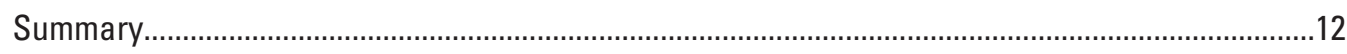

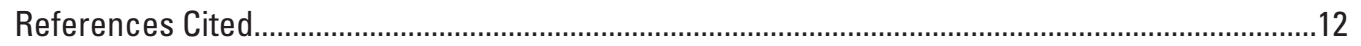

\section{Figures}

1. Map showing water-level changes in the High Plains aquifer, predevelopment

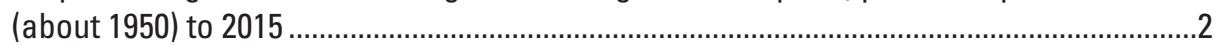

2. Map showing water-level changes in the High Plains aquifer, 2013-15...........................9

3. Map showing change in saturated thickness of the High Plains aquifer, predevelopment (about 1950) to 2015

\section{Tables}

1. Number of wells used in this report for 2013, 2014, and 2015 water levels, and for the water-level comparison periods, predevelopment (about 1950) to 2015 and 2013-15, by State and in total for the High Plains aquifer...

2. Area-weighted, average water-level changes in the High Plains aquifer, not including areas of little or no saturated thickness, predevelopment (about 1950) to 2015 and 2013-15, by State and for the aquifer as a whole...

3. Change in recoverable water in storage in the High Plains aquifer, predevelopment (about 1950) to 2015 and 2013-15, by State and for the aquifer as a whole. 


\section{Conversion Factors}

[U.S. customary units to International System of Units]

\begin{tabular}{lcl}
\hline \multicolumn{1}{c}{ Multiply } & By & \multicolumn{1}{c}{ To obtain } \\
\hline foot (ft) & Length & meter $(\mathrm{m})$ \\
\hline & 0.3048 & \\
\hline acre & Area & square meter $\left(\mathrm{m}^{2}\right)$ \\
square foot $\left(\mathrm{ft}^{2}\right)$ & 4,047 & square meter $\left(\mathrm{m}^{2}\right)$ \\
square mile $\left(\mathrm{mi}^{2}\right)^{*}$ & 0.09290 & square kilometer $\left(\mathrm{km}^{2}\right)$ \\
\hline & 2.590 & \\
\hline gallon (gal) & Volume & liter $(\mathrm{L})$ \\
gallon (gal) & 3.785 & cubic meter $\left(\mathrm{m}^{3}\right)$ \\
cubic foot (ft $\left.{ }^{3}\right)$ & 0.003785 & cubic meter $\left(\mathrm{m}^{3}\right)$ \\
acre-foot (acre-ft)** & 0.02832 & cubic meter $\left(\mathrm{m}^{3}\right)$ \\
million acre-foot (Macre-ft) & $4,047,000,000$ & square meter-foot $\left(\mathrm{m}^{2}-\mathrm{ft}\right)$ \\
million acre-foot (Macre-ft) & 1.233 .48 & cubic kilometer $\left(\mathrm{km}^{3}\right)$ \\
billion acre-foot (Bacre-ft) & $1,233.48$ & cubic kilometer $\left(\mathrm{km}^{3}\right)$ \\
\hline
\end{tabular}

*There are 640 acres in a square mile $\left(\mathrm{mi}^{2}\right)$.

${ }^{* *}$ One acre-foot of water is equivalent to the volume of water that would cover 1 acre $\left(43,560 \mathrm{ft}^{2}\right)$ to a depth of 1 foot $\left(325,851\right.$ gallons or $\left.43,560 \mathrm{ft}^{3}\right)$.

Horizontal coordinate information is referenced to the North American Datum of 1983 (NAD 83).

Water year is the 12-month period, October 1 through September 30, and is designated by the calendar year in which it ends. 


\title{
Water-Level and Recoverable Water in Storage Changes, High Plains Aquifer, Predevelopment to 2015 and 2013-15
}

\author{
By Virginia L. McGuire
}

\section{Abstract}

The High Plains aquifer underlies 111.8 million acres (about 175,000 square miles) in parts of eight States-Colorado, Kansas, Nebraska, New Mexico, Oklahoma, South Dakota, Texas, and Wyoming. Water-level declines began in parts of the High Plains aquifer soon after the beginning of substantial irrigation with groundwater in the aquifer area (about 1950). This report presents water-level changes and change in recoverable water in storage in the High Plains aquifer from predevelopment (about 1950) to 2015 and from 2013 to 2015.

The methods to calculate area-weighted, average water-level changes; change in recoverable water in storage; and total recoverable water in storage used geospatial data layers organized as rasters with a cell size of 500 meters by 500 meters, which is an area of about 62 acres. Raster datasets of water-level changes are provided for other uses.

Water-level changes from predevelopment to 2015 , by well, ranged from a rise of 84 feet to a decline of 234 feet. Water-level changes from 2013 to 2015, by well, ranged from a rise of 24 feet to a decline of 33 feet. The area-weighted, average water-level changes in the aquifer were an overall decline of 15.8 feet from predevelopment to 2015 and a decline of 0.6 feet from 2013 to 2015 . Total recoverable water in storage in the aquifer in 2015 was about 2.91 billion acrefeet, which was a decline of about 273.2 million acre-feet since predevelopment and a decline of 10.7 million acre-feet from 2013 to 2015.

\section{Introduction}

The High Plains aquifer underlies 111.8 million acres (about 175,000 square miles $\left[\mathrm{mi}^{2}\right]$ ) in parts of eight StatesColorado, Kansas, Nebraska, New Mexico, Oklahoma, South Dakota, Texas, and Wyoming (fig. 1; Qi, 2010). In the High Plains aquifer, groundwater generally is under unconfined conditions, and the water body, from a regional perspective, has a water table at which the water pressure is atmospheric (Weeks and Gutentag, 1981). The saturated thickness of the aquifer, which is the distance from the water table to the base of the aquifer, ranges from 0 feet ( $\mathrm{ft}$ ) to about 1,200 $\mathrm{ft}$ (McGuire and others, 2012). Gutentag and others (1984) reported that, in a few parts of the aquifer area, the water table is discontinuous; these areas total about 6.8 million acres (Macres; 10,690 $\mathrm{mi}^{2}$ ) and are labeled in this report's figures as "area of little or no saturated thickness." Wells drilled in areas of little or no saturated thickness (fig. 1) likely will not yield water unless the wells penetrated saturated sediment in buried channels or depressions in the bedrock surface (Gutentag and others, 1984).

The area overlying the High Plains aquifer is one of the primary agricultural regions in the Nation; in parts of the area, farmers and ranchers began extensive use of groundwater for irrigation in the 1930s and 1940s. Estimated irrigated acreage was 2.1 Macres in 1949, 13.7 Macres in 1980, 13.9 Macres in 1997, 14.7 Macres in 2002, 15.8 Macres in 2005, and 15.0 Macres in 2012 (Heimes and Luckey, 1982; Thelin and Heimes, 1987; U.S. Department of Agriculture, 1999; U.S. Geological Survey, 2015a, 2015b, 2015c). In 2012, about 14 percent of the aquifer area was irrigated, not including the areas with little or no saturated thickness (U.S. Geological Survey, 2015c).

About every 5 years, groundwater withdrawals for irrigation and other uses are compiled from water-use data and reported by the U.S. Geological Survey (USGS) and State agencies, but the withdrawals are often not identified by aquifer. Estimated groundwater withdrawals from the High Plains aquifer for irrigation increased from 4 to 19 million acre-feet (Macre-ft) from 1949 to 1974; estimated groundwater withdrawals for irrigation in 1980 were 18 Macre-ft (Heimes and Luckey, 1982, 1983). Groundwater withdrawals from the aquifer for irrigation were 21 Macre- $\mathrm{ft}$ in 2000 (Maupin and Barber, 2005).

Water-level declines began in parts of the High Plains aquifer soon after the onset of substantial irrigation using groundwater in the area (about 1950; Gutentag and others, 1984). From 1938 to 1951 , water-level declines of more than $50 \mathrm{ft}$ were documented in the High Plains aquifer in parts of Texas (Gaum, 1953). By 1980, water levels in the High Plains aquifer had declined more than $100 \mathrm{ft}$ in parts of Kansas, New Mexico, Oklahoma, and Texas; more than $50 \mathrm{ft}$ in parts of Colorado; and more than $25 \mathrm{ft}$ in parts of Nebraska and Wyoming. In contrast, by 1980, water-level changes in 


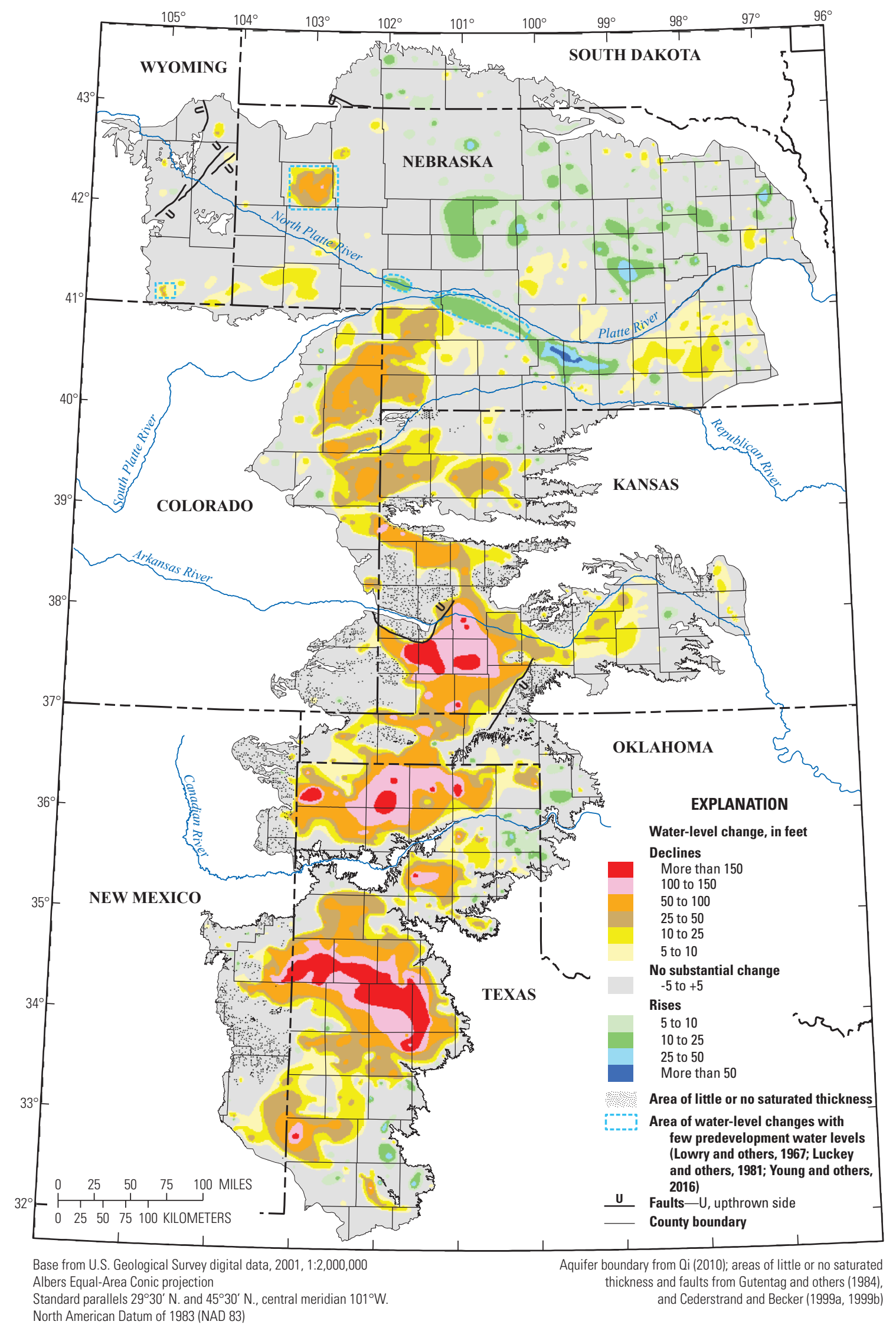

Figure 1. Water-level changes in the High Plains aquifer, predevelopment (about 1950) to 2015. 
the High Plains aquifer in South Dakota were less than $10 \mathrm{ft}$ (Luckey and others, 1981).

Changes in the static water level of an aquifer result from an imbalance between discharge and recharge. The static water level in a well is the water level after recovery from pumping in the measured well or in nearby wells. Discharge from the High Plains aquifer primarily consists of groundwater withdrawals for irrigation but it also includes groundwater withdrawals for public and domestic water supply and other uses; evapotranspiration where the water table is near land surface; and seepage to streams, springs, and other surfacewater bodies, where the water table intersects the land surface (Maupin and Barber, 2005). Recharge to the aquifer primarily is from precipitation, but other sources of recharge include irrigation return flows and seepage from streams, canals, and reservoirs (Luckey and Becker, 1999). Water-level declines may result in increased costs to pump groundwater because of increased pumping lift and decreased well yields (Taylor and Alley, 2001). Water-level declines also can affect groundwater availability, surface-water flow, and near-stream (riparian) habitat areas (Alley and others, 1999).

In response to water-level declines, Congress, under the authority of Title III to the Water Resources Research Act (Public Law 98-242 and Public Law 99-662), directed the USGS to monitor water levels in the High Plains aquifer. Since 1987, the USGS, in collaboration with numerous State, local, and Federal water-resources entities, has compiled water levels from wells completed in the High Plains aquifer. Water levels were measured in 8,327 wells for water year 2013 and 8,501 wells for water year 2014. Water levels for 2015 were based on static water-level measurements in water year 2015 for 8,307 wells and on the latest static water level measured from water year 2011 to water year 2014 for 60 wells in New Mexico and 12 wells in Wyoming, which were without static water-level measurements in 2015 (table 1). A water year is the 12-month period, October 1 through September 30, and is designated by the calendar year in which it ends.

Purposes of this report are to (1) present water-level changes in the High Plains aquifer from the time before substantial development of groundwater for irrigation (hereinafter referred to as "predevelopment") to 2015 and from 2013 to 2015 ; (2) present changes in recoverable water in storage in the High Plains aquifer, predevelopment to 2015 and 2013-15; and (3) publish the raster datasets depicting waterlevel changes, predevelopment to 2015 and 2013-15, and the applicable water-level change data.

Predevelopment generally is about 1950 , but in some areas (for example, in the north-central part of the Texas Panhandle) predevelopment is the late 1990s, and in other areas (for example, in north-central Nebraska), groundwater has not yet (2017) been substantially developed for irrigation. Recoverable water in storage is the fraction of water in the aquifer that will drain by gravity and can be withdrawn by wells. The remaining water in the aquifer is held to the aquifer material and generally cannot be withdrawn by wells (Meinzer, 1923). Water levels used in this report generally

Table 1. Number of wells used in this report for 2013, 2014, and 2015 water levels, and for the water-level comparison periods, predevelopment (about 1950) to 2015 and 2013-15, by State and in total for the High Plains aquifer.

\begin{tabular}{lrrrrrr}
\hline \multirow{2}{*}{ State } & \multicolumn{3}{c}{ Number of wells measured } & & \multicolumn{2}{c}{$\begin{array}{c}\text { Number of wells used in water-level } \\
\text { comparison for indicated period }\end{array}$} \\
\cline { 2 - 4 } \cline { 7 - 8 } \cline { 7 - 8 } & $\mathbf{2 0 1 3}$ & $\mathbf{2 0 1 4}$ & $\mathbf{2 0 1 5}$ & & Predevelopment to 2015 & $\mathbf{2 0 1 3 - 1 5}$ \\
\hline Colorado & 435 & 460 & 454 & & 335 & 411 \\
Kansas & 1,442 & 1,522 & 1,460 & & 484 & 1,315 \\
Nebraska & 3,416 & 3,551 & 3,497 & & 1,449 & 3,223 \\
New Mexico & 82 & 64 & 106 & & 1101 & 71 \\
Oklahoma & 150 & 107 & 140 & & 71 & 131 \\
South Dakota & 102 & 111 & 108 & & 67 & 98 \\
Texas & 2,680 & 2,667 & 2,536 & & 639 & 2,269 \\
Wyoming & 20 & 19 & 6 & & 218 & 6 \\
High Plains aquifer & $\mathbf{8 , 3 2 7}$ & $\mathbf{8 , 5 0 1}$ & $\mathbf{8 , 3 0 7}$ & & $\mathbf{3 , 1 6 4}$ & $\mathbf{7 , 5 2 4}$ \\
\hline
\end{tabular}

${ }^{1}$ In New Mexico, the 2015 static water levels for 60 wells with a predevelopment water level and without a 2015 static water level were estimated by the latest available static water-level measurement from 2011 through 2014. The 2015 water levels were estimated for these wells because these wells were not measured annually or the available 2015 water level was not a static water level.

${ }^{2}$ In Wyoming, the 2015 static water levels for 12 wells with a predevelopment water level and without a 2015 static water level were estimated by the latest available static water-level measurement from 2011 through 2014 . The 2015 water level was estimated for these wells because few Wyoming wells with predevelopment water levels were measured for 2015. 
were measured in winter or early spring, when irrigation wells typically were not pumping, and after water levels generally had recovered from pumping during the previous irrigation season.

\section{Data and Methods}

Area-weighted, average water-level changes, predevelopment to 2015 and 2013-15; change in recoverable water in storage, predevelopment to 2015 and 2013-15; and total recoverable water in storage in 2015 were calculated for this report using geospatial data organized as raster datasets (hereinafter referred to as "rasters"). The methods used for these calculations are the same as methods used in McGuire (2013). The final, raster datasets of water-level changes, from predevelopment to 2015 and 2013-15, are provided for other uses (McGuire, 2017).

\section{Characteristics of Raster Datasets}

For this report, rasters were generated for water-level changes and percent changes in saturated thickness, predevelopment to 2015, and for water-level changes, 2013-15. The rasters were generated using two versions of a geographic information system-Esri ${ }^{\circledR}$ ArcInfo $^{\mathrm{TM}}$ Workstation, version 9.3; and Esri ${ }^{\circledR}$ ArcMap, version 10.3.1. The Esri ${ }^{\circledR}$ ArcInfo $^{\text {TM }}$ Workstation and Esri ${ }^{\circledR}$ ArcMap commands are hereinafter referred to as "ArcGIS" commands (Esri, 1992, 2010, 2016). The rasters were georeferenced to geographic coordinates on an Albers equal-area conic projection using the North American Datum of 1983 (NAD 83). The cell size for all rasters was 500 meters $(\mathrm{m} ; 1,640.4 \mathrm{ft})$ by $500 \mathrm{~m}$ or about 62 acres. Waterlevel-change values were stored in units of feet. Changes in recoverable water in storage values were stored in units of square meter-feet. Recoverable water in storage was summarized in units of million acre-feet.

The rasters of water-level changes, predevelopment to 2015 and 2013-15, are available for download in two formats (McGuire, 2017). The interpolation process, which was used to generate the rasters, results in cell values for cells collocated with a measured well, that are generally similar to, but commonly not exactly equal to, the corresponding values based on those water-level measurements. This difference is because the cell values represent the value for the cell area and the measured values are values at specific locations within the area represented by the cell.

\section{Characteristics of Water-Level Data}

Water-level data used in this report generally were from wells measured with an electric or steel tape using methods similar to those described by Cunningham and Schalk (2011). The wells were measured by numerous State, local, and Federal water-resources agencies, and the measurement results were loaded into the USGS National Water Information System (NWIS) (U.S. Geological Survey, 2017).

Most of the wells were measured manually one to two times per water year. Generally, if a well was measured one time per water year, the well was measured in the winter or early spring (water year 2013 or 2015); if a well was measured two times per water year, the well was measured in winter or early spring and in the fall (water year 2013 or 2015). Some wells were measured nearly continuously using instrumentation (data recorders with sensors or floats) installed in the well that recorded the water level periodically (generally every 15 to 60 minutes) (Cunningham and Schalk, 2011). Water-level data used to map water-level changes were compiled for the specified water years (U.S. Geological Survey, 2017). Available water-level data for each well were reviewed to select a water level that (1) reasonably represented the recovered or static water level for each applicable water year and (2) was consistent with water levels in nearby wells. Generally, where groundwater is used for irrigation in the area overlying the High Plains aquifer, water levels in the aquifer have substantially recovered from pumping in the previous irrigation season by the late winter or early spring; often the only water level available for a particular well is measured in the late winter or early spring. The water level record for a well is reviewed to determine whether the candidate static water level differs by more than 10 feet from the previous years' static water levels in that well. In addition, if the water-levelchange value in a well differs substantially from the waterlevel-change value in nearby wells, the water-level-change records for the given well and the nearby wells are reviewed to determine if they should be used as static water levels. For example, in areas with well nests, the water levels from the wells in the well nest may reflect an upward or downward gradient, depending on hydrologic conditions and the location of the well screens in the aquifer. For this report, if the waterlevel-change value in the deeper wells within the nest differed substantially from the water level in the shallowest well, the water level from the shallowest well was generally used as the static water level. As a second example, if the water level in a well for the specified year was much closer to land surface than in previous years, the shallow water level was reviewed to determine if it should be used as a static water level. If a static water level was not available for a well for the specified water year, the water-level data for that well were not used in this report, except as noted in table 1.

Most of the measured wells supply water for irrigation; water-level precision and accuracy in irrigation wells can be adversely affected by excess oil used to lubricate the well's pump. The thickness of the excess oil and the depth to the oil-water interface can be measured with specialized waterlevel tapes or can be estimated using a method described in Cunningham and Schalk (2011); however, the specialized tapes often cannot be used in irrigation wells because the opening(s) in the well casing for the tape generally is too small for the specialized tape. If there is not oil in the well, the 
precision of the water-level measurements generally is $0.01 \mathrm{ft}$; if there is oil on the surface of the water, the precision of the water-level measurement likely is greater than $0.01 \mathrm{ft}$. For this study, methods were not used to assess the amount of oil on the surface of the water; therefore, the effect on the water-level accuracy that should be attributed to oil on the water surface cannot be assessed.

In all eight States underlain by the High Plains aquifer, available water levels for predevelopment and 1980 were compiled by Weeks and Gutentag (1981) and McGuire and others (2003). The predevelopment water level generally was estimated by using the earliest water-level measurement available for more than 20,000 wells. The median measurement year in the predevelopment period was 1957 (McGuire and others, 2003). The 1980 water levels are static water levels generally measured after the irrigation season in 1979 and before the irrigation season in 1980 (that is, in water year 1980), but some were measured 1 or 2 years earlier.

In six of the eight States that are underlain by the High Plains aquifer-Colorado, Kansas, Nebraska, Oklahoma, South Dakota, and Texas - most water-level data used in this report were from wells that are measured at least annually. In areas underlain by the High Plains aquifer in New Mexico, a substantial number of wells are measured only once every 5 years. In Wyoming, a number of the wells used in previous reports (McGuire, 2014) are no longer measured.

In Colorado, Kansas, Nebraska, Oklahoma, South Dakota, and Texas, the water levels used to map water-level changes, predevelopment to 2015 , were from wells with a static water level for predevelopment and for 2015. In New Mexico and Wyoming, the water levels used to map waterlevel changes, predevelopment to 2015, were from wells with a static water level for predevelopment and for 2015 and, if a well did not have a static water level for 2015, from wells with a static water level for predevelopment and for at least 1 year from 2011 to 2014.

Sixty wells in New Mexico and 12 wells in Wyoming were measured in predevelopment and did not have static water levels for 2015, but these wells did have static water levels for at least 1 year from 2011 to 2014. For these wells, the most recent static water level from 2011 to 2014 was used as the static water level for 2015. In New Mexico, the most recent static water level from 2011 to 2014 was used as the static water level for 2015 for 23 wells measured in water year 2011, 21 wells measured in water year 2012, 8 wells measured in water year 2013, and 8 wells measured in water year 2014 . In Wyoming, the most recent static water level from 2011 to 2014 was used as the static water level for 2015 for 10 wells measured in water year 2012 and 2 wells measured in water year 2014.

In the eight States that overlie the High Plains aquifer, the water levels used to map 2013-15 water-level changes were from wells with a static water level measured in water years 2013 and 2015. Water levels measured for other years were not used to map water-level changes, 2013-15.

\section{Characterizing Water-Level Changes, Predevelopment to 2015}

The raster of water-level changes, predevelopment to 2015 (McGuire, 2017), was generated using the same methods used in McGuire (2013) for the raster of water-level changes, predevelopment to 2011. The raster was generated using the ArcGIS command "topogrid" with the water-level-change data from wells measured in predevelopment and measured or estimated for 2015 as the primary source data, and contours of water-level change, predevelopment to 2015 , to control the interpolation. The contours of water-level change were initially generated by the ArcGIS "contour" command on the output of the ArcGIS "topogrid" command; the contours of water-level change were later manually modified using primary water-level-change data from wells measured in predevelopment and measured or estimated for 2015, published water-level-change values in areas in Nebraska and Wyoming with sparse primary water-level-change data (Lowry and others, 1967; Luckey and others, 1981; Young and others, 2016), and supplemental water-level-change data. The supplemental water-level-change data are from the following sources:

1. Wells measured before June 15, 1978, but not during or before the predevelopment period for the area, and in 2015;

2. The sum of the water-level-change value from wells measured in 1980 and 2015 and the beginning waterlevel-change value from the contours of water-level change, predevelopment to 1980 (Luckey and others, 1981);

3. In all States except New Mexico and Wyoming, wells with static water levels in predevelopment and in 2014, but not in 2015;

4. In all States except New Mexico and Wyoming, wells with static water levels in predevelopment and in 2013, but not in 2014 or 2015;

5. In all States except New Mexico and Wyoming, wells with static water levels in predevelopment and in 2012, but not in 2013, 2014, or 2015; and

6. In all States except New Mexico and Wyoming, wells with static water levels in predevelopment and in 2011, but not in 2012, 2013, 2014, or 2015.

The mapped areas between a decline of less than $5 \mathrm{ft}$ and a rise of less than $5 \mathrm{ft}$ were termed areas of no substantial change and were assigned a value of zero water-level change rather than using the ArcGIS interpolation of water-level-change values in these areas. McGuire (2013) discusses the effect of using zero in the areas of no substantial changes instead of the ArcGIS interpolation of water-level-change values. 


\section{Characterizing Water-Level Changes, 2013-15}

The raster of water-level changes, 2013-15 (McGuire, 2017), was generated using the ArcGIS command "topogrid," which is the same method used in McGuire (2013) for the raster of water-level changes, 2009-11. The mapped areas between a decline of less than $1 \mathrm{ft}$ and a rise of less than $1 \mathrm{ft}$ were termed areas of no substantial change and were assigned a value of zero water-level change rather than using the ArcGIS interpolation of water-level-change values in these areas. McGuire (2013) discusses the effect of using zero in the areas of no substantial changes instead of the ArcGIS interpolation of water-level-change values. The range of no substantial change for 2013-15 was defined differently than the range used for the predevelopment to 2015 time period because there generally are sufficient data in the 2013-15 time period to map the areas between a decline of less than $1 \mathrm{ft}$ and a rise of less than $1 \mathrm{ft}$.

\section{Characterizing Specific Yield}

Specific yield of the aquifer is needed to calculate recoverable water in storage. Specific yield of a rock or soil, with respect to water, is the ratio of the volume of water, which the saturated rock or soil will yield by gravity, to the rock or soil volume (Meinzer, 1923). Specific yield was mapped for the High Plains aquifer (Gutentag and others, 1984; Cederstrand and Becker, 1998) from weighted average specific yield derived from lithologic logs for selected wells or test holes generally drilled to the base of the aquifer. Specific-yield values derived from lithologic logs and test holes ranged from a small nonzero number to 30 percent. The area-weighted, average specific yield, not including the areas of little or no saturated thickness, ranges by State from 8.1 percent in Wyoming to 18.5 percent in Oklahoma and is 15.1 percent overall for the aquifer (Gutentag and others, 1984; McGuire and others, 2012).

A specific-yield raster was created from the digital map of specific-yield ranges in the High Plains aquifer; the published map of specific-yield ranges was derived from working maps of specific yield for each State that overlies the aquifer (Gutentag and others, 1984; Cederstrand and Becker, 1998). The ArcGIS command "polygrid" was used to convert the average of the assigned range for the specific-yield polygons to a raster of the area; the specific-yield raster is available for download from the McGuire and others (2012) report website. The specific-yield value of cells in this raster of specific yield is hereafter referred to as the "average-mapped" specific-yield value.

\section{Calculation of Area-Weighted, Average Water- Level Changes, Predevelopment to 2015 and 2013-15}

In this report, area-weighted, average water-level changes, predevelopment to 2015 and 2013-15, were calculated using the same methods used in McGuire (2013) to calculate area-weighted, average water-level changes, predevelopment to 2011 and 2009-11. This method for calculating area-weighted, average water-level changes was used because the water-level-change raster can be used to easily calculate statistics for subareas of the aquifer. Area-weighted, average water-level changes, predevelopment to 2015 and 2013-15, were calculated by State and for the aquifer as a whole.

\section{Calculation of Total Recoverable Water in Storage and Change in Recoverable Water in Storage}

Total recoverable water in storage for 2015 and changes in recoverable water in storage in the High Plains aquifer for the predevelopment to 2015 and the 2013-15 time periods were calculated by applying "map algebra" techniques (Tomlin and Berry, 1979) to coregistered rasters sharing a common cell size and mesh orientation. Total recoverable water in storage for 2015 was calculated by summing the rasters of saturated thickness for 2009 (McGuire and others, 2012) and the rasters of water-level changes, 2009-11 (McGuire, 2013), 2011-13 (McGuire, 2014), and 2013-15 (this report), then multiplying the result by the raster of the average-mapped specific yield (McGuire and others, 2012) and by a conversion factor to convert units of square meterfeet to million acre-feet. Changes in recoverable water in storage in the High Plains aquifer for the predevelopment to 2015 and the 2013-15 time periods were calculated by multiplying the raster cell values of water-level changes for each period by the raster cell values of average-mapped specific yield (McGuire and others, 2012) and by a conversion factor to convert units of square meter-feet to million acre-feet. Changes in recoverable water in storage from predevelopment to 2015 and 2013-15, by State and by the aquifer as a whole, were calculated using the applicable resultant raster.

\section{Characterizing Percentage Change in Saturated Thickness, Predevelopment to 2015}

The raster of percentage change in saturated thickness, predevelopment to 2015, was generated using the ArcGIS command "topogrid." Inputs to topogrid were percent change in saturated thickness at each well measured in predevelopment and measured or estimated for 2015, and contours of percent change in saturated thickness. Predevelopment saturated thickness was calculated for each well by subtracting the altitude of the base of aquifer from the predevelopment 
water-level altitude. The contours of percent change in saturated thickness were used to constrain the interpolation in areas of sparse data; these contours were initially generated by the ArcGIS "contour" command on the output of the ArcGIS "topogrid" command. The percent change in saturated thickness contours were manually modified using the percent change in saturated thickness value at each well measured in predevelopment and measured or estimated for 2015 and using published areas of water-level changes in Nebraska and Wyoming with few predevelopment water levels (Lowry and others, 1967; Luckey and others, 1981; Young and others, 2016). The percent change in saturated thickness contours were reviewed and, where appropriate, manually modified using supplemental data to construct the final contours. The supplemental data for changes in saturated thickness, in percent, were from the following sources:

1. In all States except New Mexico and Wyoming, wells with static water levels in predevelopment and in 2014, but not in 2015;

2. In all States except New Mexico and Wyoming, wells with static water levels in predevelopment and in 2013, but not in 2014 or 2015;

3. In all States except New Mexico and Wyoming, wells with static water levels in predevelopment and in 2012, but not in 2013, 2014, or 2015; and

4. In all States except New Mexico and Wyoming, wells with static water levels in predevelopment and in 2011, but not in 2012, 2013, 2014, or 2015.

\section{Water-Level Data}

Water-level data used in this report were provided by the following State, local, and Federal entities through data files or downloads from websites and were loaded into the USGS NWIS (U.S. Geological Survey, 2017):

- Colorado-Division of Water Resources (also known as the Office of the State Engineer) (http://water.state. co.us/Home/Pages/default.aspx);

- Kansas-Department of Agriculture, Division of Water Resources and the Kansas Geological Survey (Kansas Geological Survey, 2016);

- Nebraska - Central Nebraska Public Power and Irrigation District (http://www.cnppid.com/), University of Nebraska-Lincoln, Conservation and Survey Division (http://snr.unl.edu/csd/), and the following Natural Resources Districts:

- Central Platte (http://cpnrd.org/)

- Lewis \& Clark (http://www.lcnrd.org/)
- Little Blue (http://www.littlebluenrd.org/)

- Lower Big Blue (http://www.lbbnrd.net/)

- Lower Elkhorn (http://www.lenrd.org/)

- Lower Loup (https://www.1lnrd.org/)

- Lower Niobrara (http://www.lnnrd.org/)

- Lower Platte North (http://www.lpnnrd.org/)

- Lower Platte South (http://www.lpsnrd.org/)

- Lower Republican (https://www.lrnrd.org/)

- Middle Niobrara (http://www.mnnrd.org/)

- Middle Republican (http://www.mrnrd.org/)

- North Platte (http://www.npnrd.org)

- Papio Missouri River (http://www.papionrd.org)

- South Platte (http://www.spnrd.org)

- Tri-Basin (http://www.tribasinnrd.org/)

- Twin Platte (http://www.tpnrd.org)

- Upper Big Blue (http://www.upperbigblue.org)

- Upper Elkhorn (http://www.uenrd.org)

- Upper Loup (http://www.upperloupnrd.org)

- Upper Niobrara White (http://www.unwnrd.org)

- Upper Republican (http://www.urnrd.org);

- New Mexico-Office of the State Engineer (http:// www.ose.state.nm.us/);

- Oklahoma-Water Resources Board (https://www. owrb.ok.gov/);

- South Dakota-Department of Environment and Natural Resources (https://denr.sd.gov/);

- Texas-The Water Development Board (Texas Water Development Board, 2016) and the following Groundwater Conservation Districts:

- Garza County (http://www.garzacounty.net/id30. html)

- Gateway (http://www.gatewaygroundwater.com/)

- Glasscock (https://www.twdb.texas.gov/groundwater/conservation_districts/gcdinfo1.asp) 
- Hemphill County (https://www.twdb.texas.gov/ groundwater/conservation_districts/gcdinfo2.asp)

- High Plains No. 1(http://www.hpwd.org/)

- Llano Estacado (http://www.llanoestacadouwcd.org/)

- Mesa (http://www.mesauwcd.org/)

- Mesquite (http://www.mesquitegcd.org/)

- North Plains (http://northplainsged.org/)

- Panhandle (https://pgcd.us/)

- Permian Basin (http://www.pbuwcd.com/)

- Sandy Land (http://www.sandylandwater.com/)

- South Plains (http://www.spuwcd.org/);

- Wyoming—State Engineer's Office (https://sites. google.com/a/wyo.gov/seo/); and

- Federal-Bureau of Reclamation (https://www.usbr. gov/gp/nkao/), U.S. Fish and Wildlife Service (https:// www.fws.gov/refuge/crescent_lake/ and https://www. fws.gov/refuge/valentine/), and USGS offices in Colorado, Kansas, Nebraska, New Mexico, Oklahoma, South Dakota, Texas, and Wyoming.

The data used in this report were retrieved for each applicable State from USGS NWIS (U.S. Geological Survey, 2017). The water-level data used in this report are available for download (McGuire, 2017).

\section{Water-Level Changes}

Water-level changes in the High Plains aquifer are presented for two periods: predevelopment to 2015 and 2013-15. In addition, water-level changes are presented as the percentage change in saturated thickness from predevelopment to 2015 .

\section{Water-Level Changes, Predevelopment to 2015}

The map of water-level changes in the High Plains aquifer, predevelopment to 2015 (fig. 1), is based on water levels from 3,164 wells, including estimated water levels from 60 wells in New Mexico and 12 wells in Wyoming (table 1), and on other published data (Lowry and others, 1967; Luckey and others, 1981; Young and others, 2016). The other published data were used in areas in Nebraska and Wyoming with few predevelopment water levels (fig. 1). Water-level changes in wells, predevelopment to 2015 , ranged from

- a rise of $84 \mathrm{ft}$ in Nebraska to a decline of $234 \mathrm{ft}$ in Texas;
- a rise of $36 \mathrm{ft}$ to a decline of $193 \mathrm{ft}$ in 99 percent of the wells;

- a rise of $5 \mathrm{ft}$ to a decline of $5 \mathrm{ft}$ in 36 percent of the wells; and

- a rise of $1 \mathrm{ft}$ to a decline of $1 \mathrm{ft}$ in 10 percent of the wells.

The area-weighted, average water-level change from predevelopment to 2015 was a decline of $15.8 \mathrm{ft}$ (table 2). When summarized by State, the area-weighted, average water-level change from predevelopment to 2015 ranged from a decline of about $41.1 \mathrm{ft}$ in Texas to a rise of $0.5 \mathrm{ft}$ in South Dakota (table 2). From predevelopment to 2015, not including the areas of little or no saturated thickness, water levels declined $5 \mathrm{ft}$ or more in 36 percent of the aquifer area, $10 \mathrm{ft}$ or more in 27 percent of the aquifer area, $25 \mathrm{ft}$ or more in 19 percent of the aquifer area, and $50 \mathrm{ft}$ or more in 12 percent of the aquifer area. In approximately 57 percent of the aquifer area, water-level changes ranged from a $5-\mathrm{ft}$ decline to a $5-\mathrm{ft}$ rise, which is considered an area of no substantial change. From predevelopment to 2015 , water levels rose $5 \mathrm{ft}$ or more in 8 percent of the aquifer area and $10 \mathrm{ft}$ or more in 3 percent of the aquifer area.

Table 2. Area-weighted, average water-level changes in the High Plains aquifer, not including areas of little or no saturated thickness, predevelopment (about 1950) to 2015 and 2013-15, by State and for the aquifer as a whole.

[Positive values for water-level rises; negative values for water-level declines]

\begin{tabular}{lcc}
\hline \multirow{1}{*}{ State } & \multicolumn{2}{c}{$\begin{array}{c}\text { Area-weighted, average water-level change } \\
\text { (feet) }\end{array}$} \\
\cline { 2 - 3 } & $\begin{array}{c}\text { Predevelopment } \\
\text { to } \mathbf{2 0 1 5}\end{array}$ & $\mathbf{2 0 1 3 - 1 5}$ \\
\hline Colorado & -14.8 & -0.2 \\
Kansas & -26.2 & -1.2 \\
Nebraska & -0.9 & 0.0 \\
New Mexico & -16.5 & -0.1 \\
Oklahoma & -12.5 & -1.3 \\
South Dakota & 0.5 & 0.0 \\
Texas & -41.1 & -1.5 \\
Wyoming & -0.8 & 0.0 \\
High Plains aquifer & $\mathbf{- 1 5 . 8}$ & $\mathbf{- 0 . 6}$ \\
\hline
\end{tabular}

\section{Water-Level Changes, 2013-15}

The map of water-level changes in the High Plains aquifer, 2013-15 (fig. 2), was based on water levels from 7,524 wells measured before the irrigation season in 2013 and 2015 (table 1). Water-level changes in the measured wells ranged from 


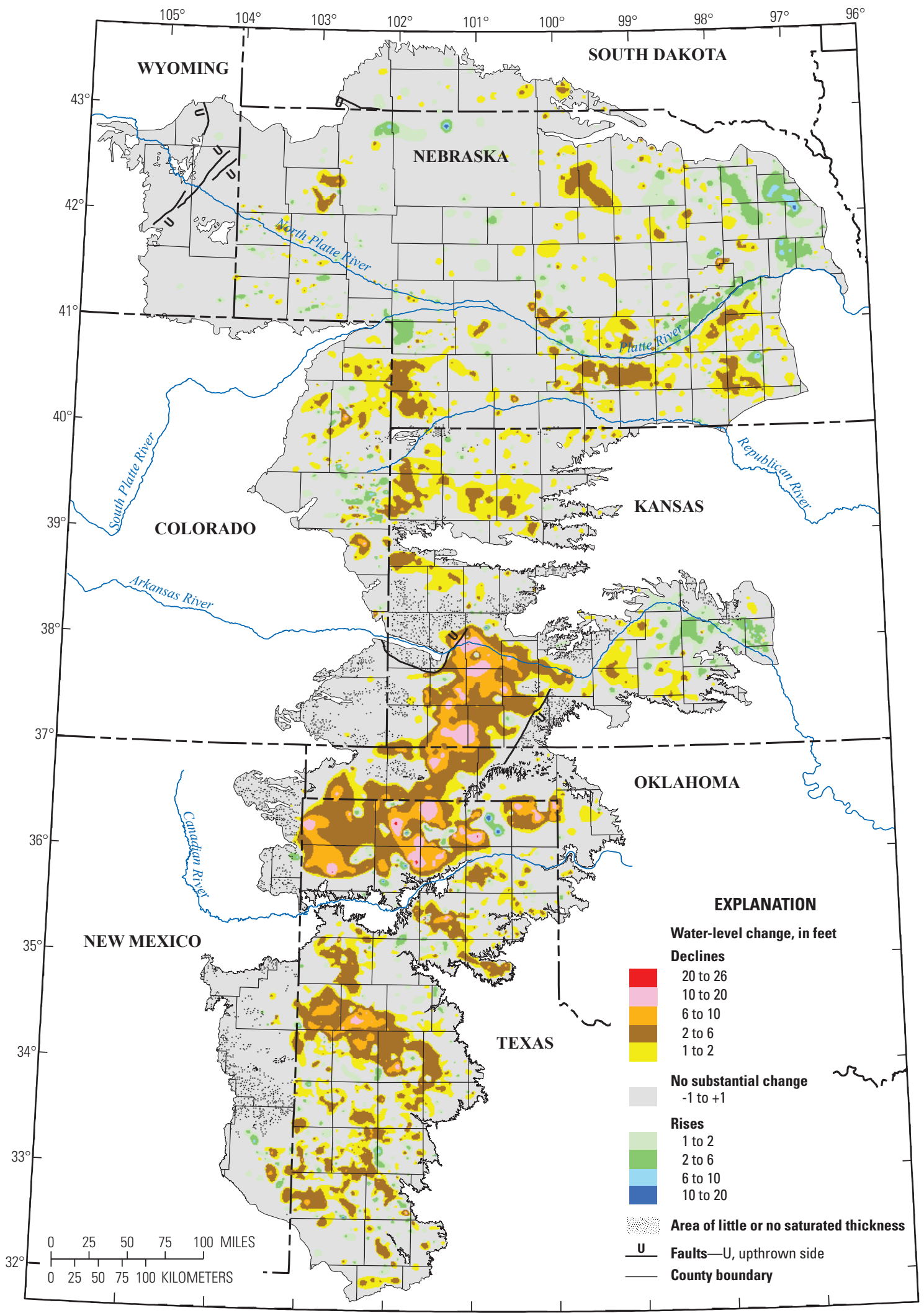

Base from U.S. Geological Survey digital data, 2001, 1:2,000,000 Albers Equal-Area Conic projection

Aquifer boundary from Qi (2010); areas of little or no saturated Standard parallels $29^{\circ} 30^{\prime} \mathrm{N}$. and $45^{\circ} 30^{\prime} \mathrm{N}$., central meridian $101^{\circ} \mathrm{W}$. thickness and faults from Gutentag and others (1984), North American Datum of 1983 (NAD 83) and Cederstrand and Becker (1999a, 1999b)

Figure 2. Water-level changes in the High Plains aquifer, 2013-15. 
- a rise of $24 \mathrm{ft}$ in Texas to a decline of $33 \mathrm{ft}$ in Texas;

- a rise of $10 \mathrm{ft}$ to a decline of $16 \mathrm{ft}$ in 99 percent of the wells;

- a rise of $5 \mathrm{ft}$ to a decline of $5 \mathrm{ft}$ in 91 percent of the wells; and

- a rise of $1 \mathrm{ft}$ to a decline of $1 \mathrm{ft}$ in 42 percent of the wells.

Water levels declined $3 \mathrm{ft}$ or more in 13 percent of the measured wells and declined $6 \mathrm{ft}$ or more in 4 percent of the measured wells. Water levels rose $3 \mathrm{ft}$ or more in 7 percent of measured wells and rose $6 \mathrm{ft}$ or more in 2 percent of measured wells. Area-weighted, average water-level changes, 2013-15, by State ranged from a $1.5-\mathrm{ft}$ decline in Texas to no change in Nebraska, South Dakota, and Wyoming. The area-weighted, average water-level change for the aquifer for the period 2013-15 was a decline of $0.6 \mathrm{ft}$ (fig. 2; table 2).

\section{Percentage Change in Saturated Thickness, Predevelopment to 2015}

The water-level changes, predevelopment to 2015 , as a percentage of predevelopment saturated thickness are shown in figure 3 . This map (fig. 3 ) is similar in some areas to the water-level-change map for the same period (fig. 1); however, a large water-level change would not correspond to a substantial percentage change in saturated thickness if the predevelopment saturated thickness was large relative to the water-level change. Conversely, an area with small water-level change may correspond to a large percentage change in saturated thickness if its predevelopment saturated thickness was small. By 2015, percentage change in saturated thickness as a percent of the aquifer area, not including the areas of little or no saturated thickness, was a decrease of 10 percent or more in 25 percent of the area, a decrease of 25 percent or more in 15 percent of the area, a decrease of 50 percent or more in 5 percent of the area, an increase of 10 percent or more in 1 percent of the area, and between a rise of 10 percent and a decline of 10 percent in 74 percent of the area.

\section{Change in Recoverable Water in Storage, Predevelopment to 2015 and 2013-15}

The recoverable volume of water in storage in the High Plains aquifer has been estimated, using different methods, to have been about 3.20 billion acre-feet (Bacre-ft) at predevelopment (McGuire and others, 2012), 3.25 Bacre-ft in 1980 (Gutentag and others, 1984), 2.98 Bacre-ft in 2000 (McGuire and others, 2003), 2.96 Bacre-ft in 2009 (McGuire and others, 2012), and 2.92 Bacre-ft in 2013 (McGuire, 2014). Recoverable water in storage in the High Plains aquifer in 2015 is estimated in this report as 2.91 Bacre-ft. Recoverable water in storage for 2015 was calculated using the rasters of water-level changes for 2009-11 (McGuire, 2013), 2011-13 (McGuire, 2014), and 2013-15 (this report); the raster of saturated thickness for 2009 (McGuire and others, 2012); and the raster of average-mapped specific yield (McGuire and others, 2012).

Change in recoverable water in storage, predevelopment to 2015, which was calculated using average-mapped specific yield, declined 273.2 Macre-ft for the aquifer overall (table 3) or about a 9-percent decline in storage since predevelopment (McGuire and others, 2012). Changes in storage, predevelopment to 2015, by State, ranged from a decline of about 157.6 Macre-ft in Texas to a rise of 0.1 Macre-ft in South Dakota (table 3). Recoverable water in storage, 2013-15, declined 10.7 Macre-ft overall; changes in recoverable water in storage, 2013-15, by State, ranged from a decline of 5.8 Macre-ft in Texas to no change in South Dakota and Wyoming (table 3).

Table 3. Change in recoverable water in storage in the High Plains aquifer, predevelopment (about 1950) to 2015 and 2013-15, by State and for the aquifer as a whole.

[Positive values for increases in recoverable water in storage; negative values for decreases in recoverable water in storage]

\begin{tabular}{lcc}
\hline \multirow{1}{*}{ State } & \multicolumn{2}{c}{$\begin{array}{c}\text { Change in recoverable water in storage } \\
\text { (million acre-feet) }\end{array}$} \\
\cline { 2 - 3 } & $\begin{array}{c}\text { Predevelopment to } \\
\mathbf{2 0 1 5}\end{array}$ & $\mathbf{2 0 1 3 - 1 5}$ \\
\hline Colorado & -19.6 & -0.2 \\
Kansas & -69.3 & -3.2 \\
Nebraska & -6.0 & -0.3 \\
New Mexico & -9.7 & -0.1 \\
Oklahoma & -10.7 & -1.1 \\
South Dakota & 0.1 & 0.0 \\
Texas & -157.6 & -5.8 \\
Wyoming & -0.4 & 0.0 \\
High Plains aquifer & $\mathbf{- 2 7 3 . 2}$ & $\mathbf{- 1 0 . 7}$ \\
\hline
\end{tabular}




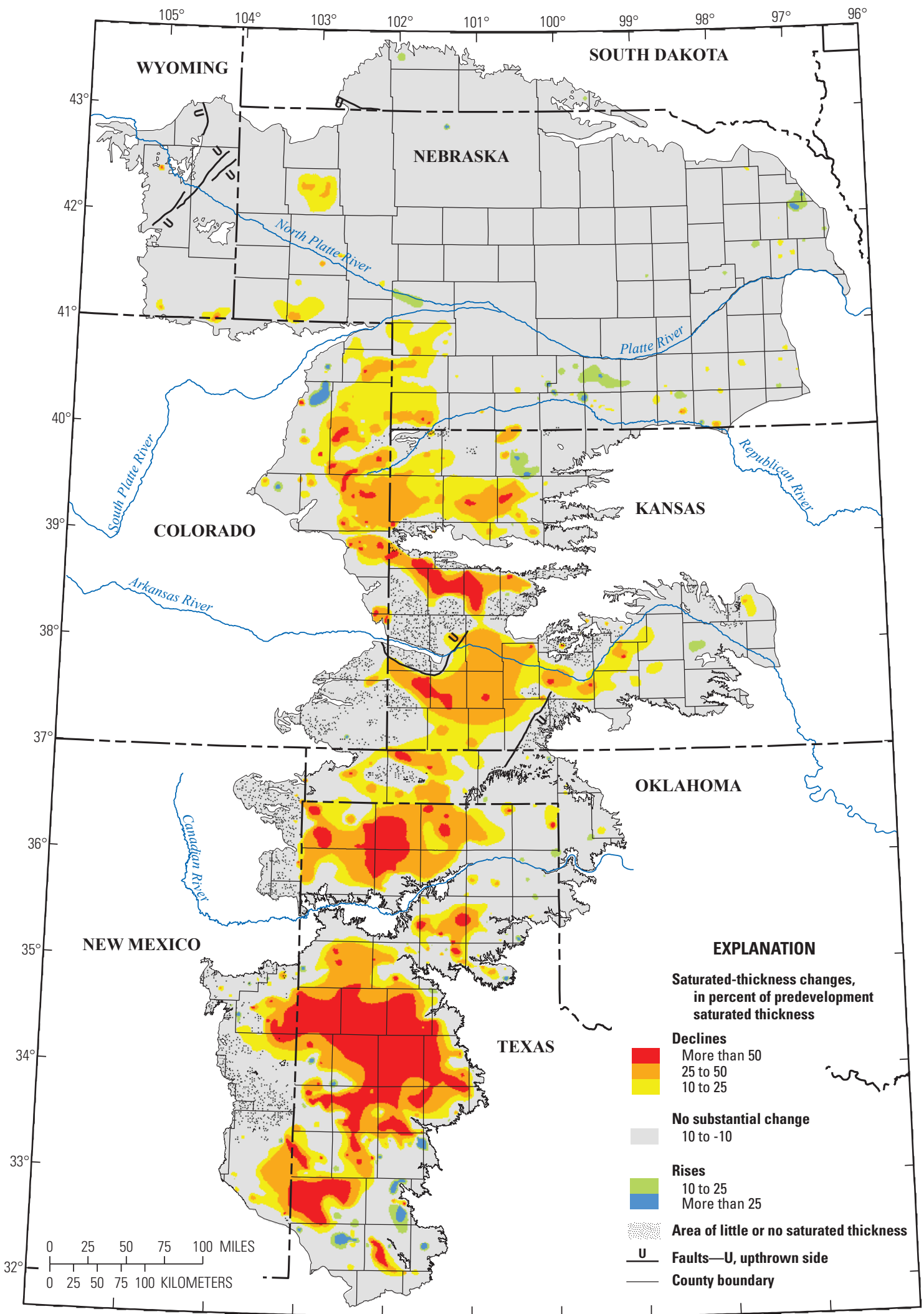

Base from U.S. Geological Survey digital data, 2001, 1:2,000,000 Albers Equal-Area Conic projection

Standard parallels $29^{\circ} 30^{\prime} \mathrm{N}$. and $45^{\circ} 30^{\prime} \mathrm{N}$., central meridian $101^{\circ} \mathrm{W}$.

Aquifer boundary from 0i (2010): change in saturated thickness since predevelopment modified from Luckey and others (1981) areas of little or no saturated thickness and faults from Gutentag and others (1984), and Cederstrand and Becker (1999a, 1999b)

Figure 3. Change in saturated thickness of the High Plains aquifer, predevelopment (about 1950) to 2015. 


\section{Summary}

The High Plains aquifer underlies 111.8 million acres (about 175,000 square miles) in parts of eight States-Colorado, Kansas, Nebraska, New Mexico, Oklahoma, South Dakota, Texas, and Wyoming. Water-level declines began in parts of the High Plains aquifer soon after the onset of substantial irrigation with groundwater (about 1950). In response to the water-level declines, Congress directed the U.S. Geological Survey to monitor water levels in the High Plains aquifer. Since 1987, the U.S. Geological Survey, in collaboration with numerous State, local, and Federal water-resources entities, has compiled water levels from wells completed in the High Plains aquifer. Water levels were measured in 8,327 wells for 2013 and in 8,307 wells for 2015. For 60 wells in New Mexico and 12 wells in Wyoming, water levels were estimated for 2015 using the latest static water level measured from 2011 to 2014 , if the well had a predevelopment water level but did not have a static water level measured in 2015.

This report presents water-level changes in the High Plains aquifer from predevelopment (about 1950) to 2015 and 2013-15. The water levels used in this report generally were measured in winter or early spring, when irrigation wells typically were not pumping, and after water levels generally had recovered from pumping during the previous irrigation season. The report also presents total recoverable water in storage in 2015 and changes in recoverable water in storage from predevelopment to 2015 and 2013 to 2015 . The methods to calculate area-weighted, average water-level changes; change in recoverable water in storage; and total recoverable water in storage used geospatial data layers organized as rasters with a cell size of 500 meters by 500 meters, which is an area of about 62 acres. Raster datasets of water-level changes, predevelopment to 2015 and 2013-15, are provided for other uses.

The map of water-level changes in the High Plains aquifer from predevelopment to 2015 is based on water levels from 3,164 wells and other published data. Water-level changes from predevelopment to 2015, in individual wells, ranged from a rise of 84 feet ( $\mathrm{ft}$ ) in Nebraska to a decline of $234 \mathrm{ft}$ in Texas. The area-weighted, average water-level change from predevelopment to 2015 was an overall decline of $15.8 \mathrm{ft}$.

Water levels were measured in 7,524 wells before the irrigation season in 2013 and 2015; water-level changes in the measured wells ranged from a $33-\mathrm{ft}$ decline in Texas to a $24-\mathrm{ft}$ rise in Texas. The area-weighted, average water-level change in the High Plains aquifer, 2013-15, was a decline of $0.6 \mathrm{ft}$.

Total recoverable water in storage in 2015 was about 2.91 billion acre-feet overall, which was a decline of about 273.2 million acre-feet (Macre-ft; or about 9 percent) since predevelopment. Changes in storage, predevelopment to 2015 , by State, ranged from a decline of about 157.6 Macre- $\mathrm{ft}$ in Texas to a rise of 0.1 Macre-ft in South Dakota. Recoverable water in storage, 2013-15, declined 10.7 Macre-ft overall; changes in recoverable water in storage, 2013-15, by State ranged from a decline of 5.8 Macre-ft in Texas to no change in South
Dakota and Wyoming. By 2015, 15 percent of the aquifer area had a decrease in saturated thickness of more than 25 percent from its predevelopment saturated thickness, 5 percent of the aquifer area had more than a 50-percent decrease, and about 1 percent of the aquifer area had more than a 10-percent increase.

\section{References Cited}

Alley, W.M., Reilly, T.E., and Franke, O.L., 1999, Sustainability of ground-water resources: U.S. Geological Survey Circular 1186, 79 p. [Also available at http://pubs.usgs.gov/ circ/circ1186/.]

Cederstrand, J.R., and Becker, M.F., 1998, Digital map of specific yield for High Plains aquifer in parts of Colorado, Kansas, Nebraska, New Mexico, Oklahoma, South Dakota, Texas, and Wyoming: U.S. Geological Survey Open-File Report 98-414, accessed August 2011 at http://water.usgs. gov/GIS/metadata/usgswrd/XML/ofr98-414.xml.

Cederstrand, J.R., and Becker, M.F., 1999a, Digital map of geologic faults for the High Plains Aquifer in parts of Colorado, Kansas, Nebraska, New Mexico, Oklahoma, South Dakota, Texas, and Wyoming: U.S. Geological Survey Open-File Report 99-261, accessed August 2011 at http:// water.usgs.gov/GIS/metadata/usgswrd/XML/ofr99-261.xml.

Cederstrand, J.R., and Becker, M.F., 1999b, Digital map of areas of little or no saturated thickness for the High Plains Aquifer in parts of Colorado, Kansas, Nebraska, New Mexico, Oklahoma, South Dakota, Texas, and Wyoming: U.S. Geological Survey Open-File Report 99-266, accessed August 2011 at http://water.usgs.gov/GIS/metadata/ usgswrd/XML/ofr99-266.xml.

Cunningham, W.L., and Schalk, C.W., comps., 2011, Groundwater technical procedures of the U.S. Geological Survey: U.S. Geological Survey Techniques and Methods, book 1, chap. A1, 151 p., accessed October 2014 at http://pubs.usgs. gov/tm/1a1/.

Esri, 1992, Understanding GIS-The Arc/Info method: Redlands, Calif., Esri, 450 p.

Esri, 2010, ArcDoc version 9.3: Redlands, Calif., Esri software documentation [online documentation and instructions included with GIS software].

Esri, 2016, ArcMap version 10.3.1: Redlands, Calif., Esri software documentation [online documentation and instructions included with GIS software]. 
Gaum, C.H., 1953, High Plains, or Llano Estacado, TexasNew Mexico, chap. 6 of The physical and economic foundation of natural resources - Volume 4, Subsurface facilities of water management and patterns of supply-Type area studies: Interior and Insular Affairs Committee, House of Representatives, United States Congress, p. 94-104.

Gutentag, E.D., Heimes, F.J., Krothe, N.C., Luckey, R.R., and Weeks, J.B., 1984, Geohydrology of the High Plains aquifer in parts of Colorado, Kansas, Nebraska, New Mexico, Oklahoma, South Dakota, Texas, and Wyoming: U.S. Geological Survey Professional Paper 1400-B, 63 p. [Also available at http://pubs.usgs.gov/pp/1400b/report.pdf.]

Heimes, F.J., and Luckey, R.R., 1982, Method for estimating historical irrigation requirements from ground water in the High Plains in parts of Colorado, Kansas, Nebraska, New Mexico, Oklahoma, South Dakota, Texas, and Wyoming: U.S. Geological Survey Water-Resources Investigations Report 82-40, 64 p.

Heimes, F.J., and Luckey, R.R., 1983, Estimating 1980 ground-water pumpage for irrigation on the High Plains in parts of Colorado, Kansas, Nebraska, New Mexico, Oklahoma, South Dakota, Texas, and Wyoming: U.S. Geological Survey Water-Resources Investigations Report 83-4123, 40 p. [Also available at https://pubs.er.usgs.gov/publication/ wri834123.]

Kansas Geological Survey, 2016, Wizard water well levels database: Lawrence, Kansas Geological Survey digital data, accessed February 2016 at http://www.kgs.ku.edu/ Magellan/WaterLevels/index.html.

Lowry, M.E., Crist, M.A., and Tilstra, J.R., 1967, Geology and ground-water resources of Laramie County, Wyoming, with a section on Chemical quality of ground water and of surface water, by J.R. Tilstra: U.S. Geological Survey Water-Supply Paper 1834, 71 p. [Also available at http:// pubs.er.usgs.gov/publication/wsp1834.]

Luckey, R.R., and Becker, M.F., 1999, Hydrogeology, water use, and simulation of flow in the High Plains aquifer in northwestern Oklahoma, southeastern Colorado, southwestern Kansas, northeastern New Mexico, and northwestern Texas: U.S. Geological Survey Water-Resources Investigations Report 99-4104, 68 p. [Also available at http://pubs.usgs.gov/wri/wri994104/.]

Luckey, R.R., Gutentag, E.D., and Weeks, J.B., 1981, Waterlevel and saturated-thickness changes, predevelopment to 1980, in the High Plains aquifer in parts of Colorado, Kansas, Nebraska, New Mexico, Oklahoma, South Dakota, Texas, and Wyoming: U.S. Geological Survey Hydrologic Investigations Atlas HA-652, 2 sheets, scale 1:2,500,000. [Also available at http://pubs.er.usgs.gov/publication/ ha652.]
Maupin, M.A., and Barber, N.L., 2005, Estimated withdrawals from principal aquifers in the United States, 2000: U.S. Geological Survey Circular 1279, 46 p. [Also available at http://pubs.usgs.gov/circ/2005/1279/.]

McGuire, V.L., 2013, Water-level and storage changes in the High Plains aquifer, predevelopment to 2011 and 2009-11: U.S. Geological Survey Scientific Investigations Report 2012-5291, 15 p. [Also available at http://pubs.usgs.gov/ $\operatorname{sir} / 2012 / 5291 /$.

McGuire, V.L., 2014, Water-level changes and change in water in storage in the High Plains aquifer, predevelopment to 2013 and 2011-13: U.S. Geological Survey Scientific Investigations Report 2014-5218, 14 p. [Also available at http:// dx.doi.org/10.3133/sir20145218.]

McGuire, V.L., 2017, Data from maps of water-level changes in the High Plains aquifer in parts of Colorado, Kansas, Nebraska, New Mexico, Oklahoma, South Dakota, Texas, and Wyoming, predevelopment (about 1950) to 2015 and 2013-15: U.S. Geological Survey data release, accessed February 2017 at https://doi.org/10.5066/F7SB43WM.

McGuire, V.L., Johnson, M.R., Schieffer, R.L., Stanton, J.S., Sebree, S.K., and Verstraeten, I.M., 2003, Water in storage and approaches to ground-water management, High Plains aquifer, 2000: U.S. Geological Survey Circular 1243, 51 p. [Also available at http://pubs.usgs.gov/circ/2003/circ1243/.]

McGuire, V.L., Lund, K.D., and Densmore, B.K., 2012, Saturated thickness and water in storage in the High Plains aquifer, 2009, and water-level changes and changes in water in storage in the High Plains aquifer, 1980 to 1995, 1995 to 2000, 2000 to 2005, and 2005 to 2009: U.S. Geological Survey Scientific Investigations Report 2012-5177, 28 p. [Also available at http://pubs.usgs.gov/sir/2012/5177/.]

Meinzer, O.E., 1923, Outline of ground-water hydrology, with definitions: U.S. Geological Survey Water-Supply Paper 494, 71 p. [Also available at http://pubs.usgs.gov/wsp/0494/ report.pdf.]

Qi, S.L., 2010, Digital map of aquifer boundary for the High Plains aquifer in parts of Colorado, Kansas, Nebraska, New Mexico, Oklahoma, South Dakota, Texas, and Wyoming: U.S. Geological Survey Data Series 543. [Also available at http://pubs.usgs.gov/ds/543/.]

Taylor, C.J., and Alley, W.M., 2001, Ground-water-level monitoring and the importance of long-term water-level data: U.S. Geological Survey Circular 1217, 68 p. [Also available at http://pubs.usgs.gov/circ/circ1217/.]

Texas Water Development Board, 2016, Groundwater database: Austin, Texas Water Development Board digital data: accessed February 2016 at http://www.twdb.texas.gov/ groundwater/data/gwdbrpt.asp. 
Thelin, G.P., and Heimes, F.J., 1987, Mapping irrigated cropland from Landsat data for determination of water use from the High Plains aquifer in parts of Colorado, Kansas, Nebraska, New Mexico, Oklahoma, South Dakota, Texas, and Wyoming: U.S. Geological Survey Professional Paper 1400-C, 38 p. [Also available at http://pubs.usgs.gov/ pp/1400c/report.pdf.]

Tomlin, C.D., and Berry, J.K., 1979, A mathematical structure for cartographic modeling in environmental analysis, in American Congress on Surveying and Mapping, 39th, Washington, D.C., 1979, Proceedings: Falls Church, Va., American Congress on Surveying and Mapping, p. 269-283.

U.S. Department of Agriculture, 1999, 1997 Census of agriculture, volume 1, geographic area series, part 51: National Agricultural Statistics Service, AC97-CD-VOL1-1B, CDROM.

U.S. Geological Survey, 2015a, The 2002 Moderate Resolution Imaging Spectroradiometer (MODIS) Irrigated Agriculture Dataset for the United States (MIrAD-US): U.S. Geological Survey spatial data, accessed July 2016 at http:// earlywarning.usgs.gov/USirrigation/.

U.S. Geological Survey, 2015b, The 2007 Moderate Resolution Imaging Spectroradiometer (MODIS) Irrigated Agriculture Dataset for the United States (MIrAD-US): U.S. Geological Survey spatial data, accessed July 2016 at http:// earlywarning.usgs.gov/USirrigation/.
U.S. Geological Survey, 2015c, The 2012 Moderate Resolution Imaging Spectroradiometer (MODIS) Irrigated Agriculture Dataset for the United States (MIrAD-US): U.S. Geological Survey spatial data, accessed July 2016 at http:// earlywarning.usgs.gov/USirrigation/.

U.S. Geological Survey, 2017, National Water Information System-Web interface: accessed January 2017, at http:// dx.doi.org/10.5066/F7P55KJN.

Weeks, J.B., and Gutentag, E.D., 1981, Bedrock geology, altitude of base, and 1980 saturated thickness of the High Plains aquifer in parts of Colorado, Kansas, Nebraska, New Mexico, Oklahoma, South Dakota, Texas, and Wyoming: U.S. Geological Survey Hydrologic Investigations Atlas HA-648, 2 sheets, scale 1:2,500,000. [Also available at http://pubs.er.usgs.gov/publication/ha648.]

Young, A.R., Burbach, M.E., and Howard, L.M., 2016, Nebraska statewide groundwater-level monitoring report 2015: University of Nebraska - Lincoln, Conservation and Survey Division, School of Natural Resources, Nebraska Water Survey Paper Number 83, 28 p., accessed December 2016 at http://snr.unl.edu/csd-esic/GWMapArchives/ GWReports/GW_Level_Report_2015.pdf.

\footnotetext{
Publishing support provided by:
} Rolla Publishing Service Center

For additional information concerning this publication, contact: Director, USGS Nebraska Water Science Center 5231 South 19th Street Lincoln, NE 68512

(402) 328-4100

Or visit the Nebraska Water Science Center website at: https://ne.water.usgs.gov 


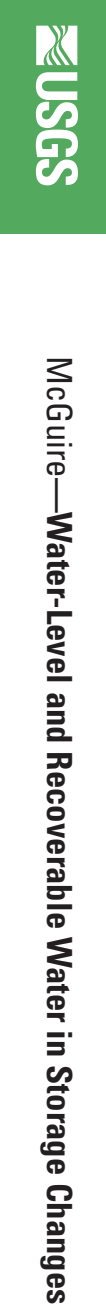

志

흘.

言.

$\frac{1}{10}$

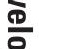

SSN 2328-0328 (online) 